Bursala O.L., Golub V.M., Cherednikov O.M., Chupryna V.M. State Scientific Research Institute of Armament and Military Equipment Testing and Certification

Kovalenko I.V. 1285 Military Representatives of the Ministry of Defense of Ukraine

\title{
DETERMINATION OF OPERATIONAL RELIABILITY INDICATORS OF AVIATION EQUIPMENT TAKING INTO ACCOUNT ICAO RECOMMENDATIONS
}

On the basis of the developed technique for estimation of aviation equipment reliability indicators, the results of determination of orientating reliability indicators of helicopters and their functional systems are presented. The list and the main reasons for the change of reliability indicators for 2016-2020 are determined.

Keywords: aircraft, helicopter, fault, operational reliability, flight safety, methodology, ICAO recommendations.

1. Introduction. The level of reliability of aircraft in operation should be defined as the total reliability of the stages of design, manufacture and operation. It is at the last stage, that the operational reliability of the aircraft is actually determined.

The operational reliability of the aircraft means the reliability determined in real operating conditions, taking into account the complex impact of internal and external factors related to the actual modes of operation of units, assemblies, systems of aircraft and their service conditions as well as climatic and geographical features of aircraft operation.

Operational reliability is to some extent a guarantee of aircraft flight safety. The complexity of the problem of flight safety is that it depends on many factors that occur at all stages of the life cycle of the aircraft.

Automation, computer equipment, complex aviation and electronic equipments are intensively implemented on modern aircraft. But, despite the increase in the reliability of individual elements, the reliability of the system, and hence the aircraft as a whole, can not only increase but sometimes decrease, as the probability of failure and damage with increasing number of elements increases. Insufficient reliability of aircraft causes large material costs and moral damage [1].

Many researchers in the world study the problem of operational reliability and flight safety of different types of aircraft, both in civil and military aviation [2,3]. At the same time, modern technologies for ensuring the safety of aircraft are being developed and applied $[4,5]$.

In today's world, safety needs to be considered in conjunction with reliability theory and the factors that can be managed to improve operational reliability and therefore safety are clearly understood.

Consideration of operational reliability indicators and determination of the specific value of their sufficient level is necessary to improve the safety management system. In addition, the operational reliability of the aircraft is one of the most important characteristics of determining the economic performance of aircraft repair plants (ARP). These indicators are determined by the method of visual observation and quality control on the functional basis of the work and logical analysis of the algorithm of the aircraft crew to ensure the reliability and safe operation of the aircraft.

In addition, in accordance with Annex 19 of the International Civil Aviation Organization (ICAO) $[6,7,8]$, it is recommended to determine flight safety indicators and their target levels using a relative accident rate indicator, which takes into account the total number of flight failures detected per 100 hours of flight and is calculated according to the formula [9]:

where $n$ is number of failures per year;

$$
R_{I C A O}=\frac{n}{T} \times 100,
$$

$T$ is total volume of flight per year. 
In order to select the confidence probability, as well as the relative error in assessing the performance of operational reliability, we will conduct a study of information about faults on the operational data of the aircraft.

The main purpose of reliability analysis is to determine the causal relationship between quantitative and qualitative indicators of reliability and the level of flight safety, which lead to undesirable aviation events: failures, damage, incidents (hereinafter failures).

The aim of the study is to determine the indicators of operational reliability and flight safety, taking into account the ICAO recommendations based on statistics on malfunctions that occur during the operation of the aircraft.

2. Methods and materials. According to the developed improved methodology, using the statistical data obtained during the operation of the aircraft, it is possible to calculate the point indicators of operational reliability and flight safety of the aircraft $[10,11]$. This methodology takes into account the impact on the aircraft condition of the conditions and modes of operation of the aircraft, their design and operating rules.

Figure 1 shows a block diagram of this methodology.

The algorithm for processing statistical information received from aviation units in the form of reports and fault accounting cards (FAC) consists of the following stages:

1) systematization of the reporting statistical information on failures and damages (malfunctions);

2) the division of the total amount of information into two groups:

faults recorded in different types of aircraft;

faults recorded in different types of helicopters;

3) grouping of faults by types of "specialties": "airplane, helicopter and engine" (AHaE), "aviation armament" (AA), "aviation equipment" (AE), "radio electronic equipment" (REE), "aviation sighting and navigation complex" (ASNC);

4) for each "specialty" there is the distribution and analysis of failures on the following indicators:

by systems;

by types of preparations and scheduled work;

by types of revisions on industry bulletins;

5) calculation of the following point indicators that characterize the level of operational reliability, flight safety and combat mission performance for each "specialty" and for each type of aircraft:

flying time on incident that leads to non-performance of a flight task (indicator of flight mission performance), $\mathrm{T}_{\text {INC }}$ hour/incident;

flying time on failure, which was found in flight (flight safety indicator), $\mathrm{T}_{\mathrm{S}}$ hour/failure;

flying time on malfunction that was found in flight and on the ground (indicator of operational reliability), $T_{R}$ hour/malfunction;

6) calculation of average values of reliability indicators for different specialties and types of aircraft;

7) analysis of the results obtained in the following areas:

identification of the least reliable types of aircraft;

identification of the least reliable systems by specialties;

identification of the most effective types of training and routine work on the aircraft;

determination of the most probable reasons for failures of aircraft products: for the professional activity of the flight crew (FC), the quality of work on the aircraft engineering and technical staff (ETS), the impact of structural and production defects (SPD), defects in ARP

determination of the trend of changes in the level of reliability of the aircraft and its systems, using the flow rate of reliability "failure rate parameter $z(t)$ " at a confidence level $\beta=0.95$;

8) analysis of complaints sent to the ARP;

9) determining areas to increase the reliability of aircraft. 


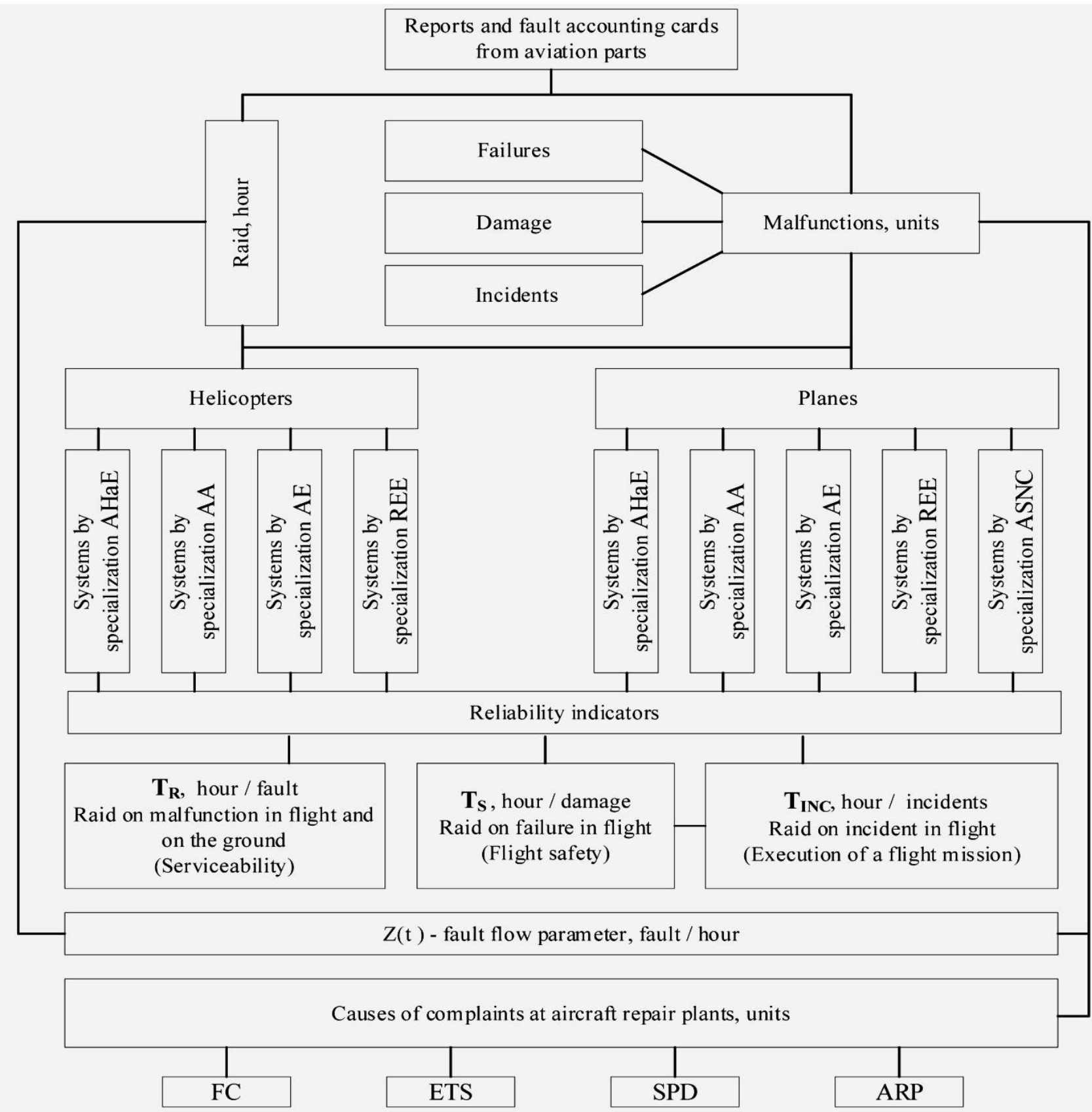

Figure 1. Block diagram of the improved methodology

As operational reliability is impacted by internal and external factors, it is necessary to carry out:

ranking of point indicators of reliability, which make it possible to determine the impact of internal factors: systems by specialties and types of work on the aircraft;

determination of the impact of time as well as geographical and climatic conditions using the reliability indicator "failure rate parameter $z(t)$ " with a confidence level $\beta=0.95$.

3. Results. The practical application of the improved methodology will be considered on the example of statistical processing of operational indicators of state aviation helicopters during 2016-2019 [12, 13, 14]. flight.

The article presents data only on the operation of helicopters that had the largest amount of

The final table 1 and Figure 2 presents the results of processing, analysis and calculations of operational statistics of certain types of helicopters and calculations of average indicators of their operational reliability. 
Average values of operational reliability indicators of helicopters for 2016-2019

\begin{tabular}{|c|c|c|c|c|c|}
\hline \multirow[b]{2}{*}{ Name of indicator } & \multicolumn{4}{|c|}{ Type of helicopter } & \multirow[b]{2}{*}{ 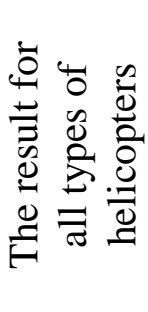 } \\
\hline & $\stackrel{i}{i}$ & 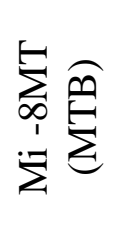 & $\begin{array}{l}>> \\
0 \\
\infty \\
\sum_{\infty}^{\infty} \\
i \\
\sum \\
i\end{array}$ & $\begin{array}{l}\stackrel{+}{*} \\
\stackrel{i}{\Sigma}\end{array}$ & \\
\hline Raid for $2016, \mathrm{~h}$ & 1018 & 7082 & 2000 & 4340 & 14140 \\
\hline Total number of faults & 16 & 106 & 81 & 70 & 273 \\
\hline Fault flow parameter & 0.016 & 0.015 & 0.041 & 0.016 & 0.019 \\
\hline $\begin{array}{l}\text { Average value by types of } \\
\text { helicopters, hour / malfunction }\end{array}$ & 491 & 306 & 194 & 341 & - \\
\hline Raid for $2017, \mathrm{~h}$ & 455 & 8072 & 2059 & 3520 & 14106 \\
\hline Total number of faults & 25 & 236 & 50 & 91 & 402 \\
\hline Fault flow parameter & 0.055 & 0.029 & 0.024 & 0.026 & 0.028 \\
\hline $\begin{array}{l}\text { Average value by types of } \\
\text { helicopters, hour/malfunction }\end{array}$ & 79 & 258 & 279 & 165 & - \\
\hline Raid for $2018, \mathrm{~h}$ & 908 & 9218 & 2244 & 2313 & 14683 \\
\hline Total number of faults & 50 & 250 & 82 & 85 & 467 \\
\hline Fault flow parameter & 0.055 & 0.027 & 0.036 & 0.037 & 0.032 \\
\hline $\begin{array}{l}\text { Average value by types of } \\
\text { helicopters, hour / malfunction }\end{array}$ & 65 & 420 & 124 & 121 & - \\
\hline Raid for $2019, \mathrm{~h}$ & 11 & 9135 & 4678 & 2493 & 16317 \\
\hline Total number of faults & 1 & 244 & 160 & 96 & 501 \\
\hline Fault flow parameter & 0.090 & 0.026 & 0.034 & 0.038 & 0.031 \\
\hline $\begin{array}{l}\text { Average value by types of } \\
\text { helicopters, hour/malfunction }\end{array}$ & 11 & 300 & 362 & 159 & - \\
\hline
\end{tabular}
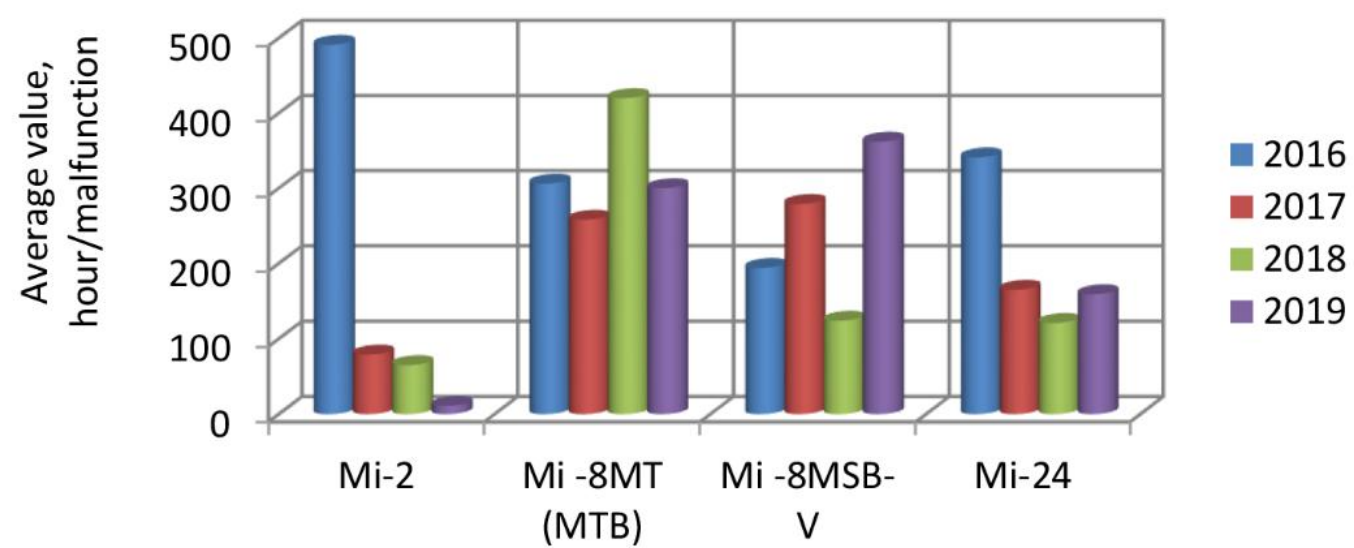

Figure 2. Average values of operational reliability indicators by types of helicopters by years

According to the results of the analysis for the period 2016-2019, there are significant changes in the operational reliability of helicopters:

- for Mi-2 helicopters, a decrease from 491 hour / malfunction in 2016 to 11 hour / malfunction in 2019, which is a negative phenomenon; 
- helicopters of the Mi-8MSB-V type, on the contrary, increased from 194 hour / malfunction in 2016 to 362 hour / malfunction in 2019;

- Mi-2 helicopters received the largest decrease by $82,2 \%$;

- Mi-8MSB-V helicopters showed an increase in the level of operational reliability by $17.1 \%$;

- in 2016, helicopters of the type had the highest level of operational reliability;

- Mi-2, and the lowest level of flight safety had helicopters type Mi-8MSB-V;

- in 2017, helicopters of the type had the highest level of operational reliability;

- Mi-8MSB-V, and the lowest level of flight safety had helicopters type Mi-2;

- in 2018, helicopters of the type had the highest level of operational reliability;

- Mi-8MT (MTV), and the lowest level of flight safety had helicopters type Mi-2;

- in 2019, helicopters had the highest level of operational reliability;

- Mi-8MSB-V, and the lowest level of flight safety had helicopters type Mi-2.

Studies of the trend of changing the point limits of operational reliability indicators make it possible to identify weaknesses in different types of aircraft, and show the impact of functional systems and types of work on aircraft in different "specialties" of aircraft on the level of these indicators [7], as shown in Figures 3 and 4.

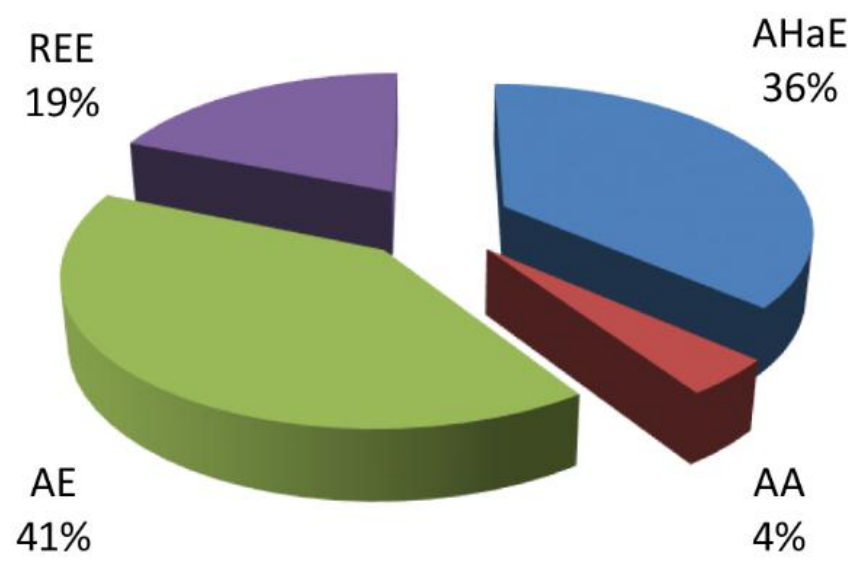

Figure 3. The impact of "specialty" on the level of operational reliability of helicopters

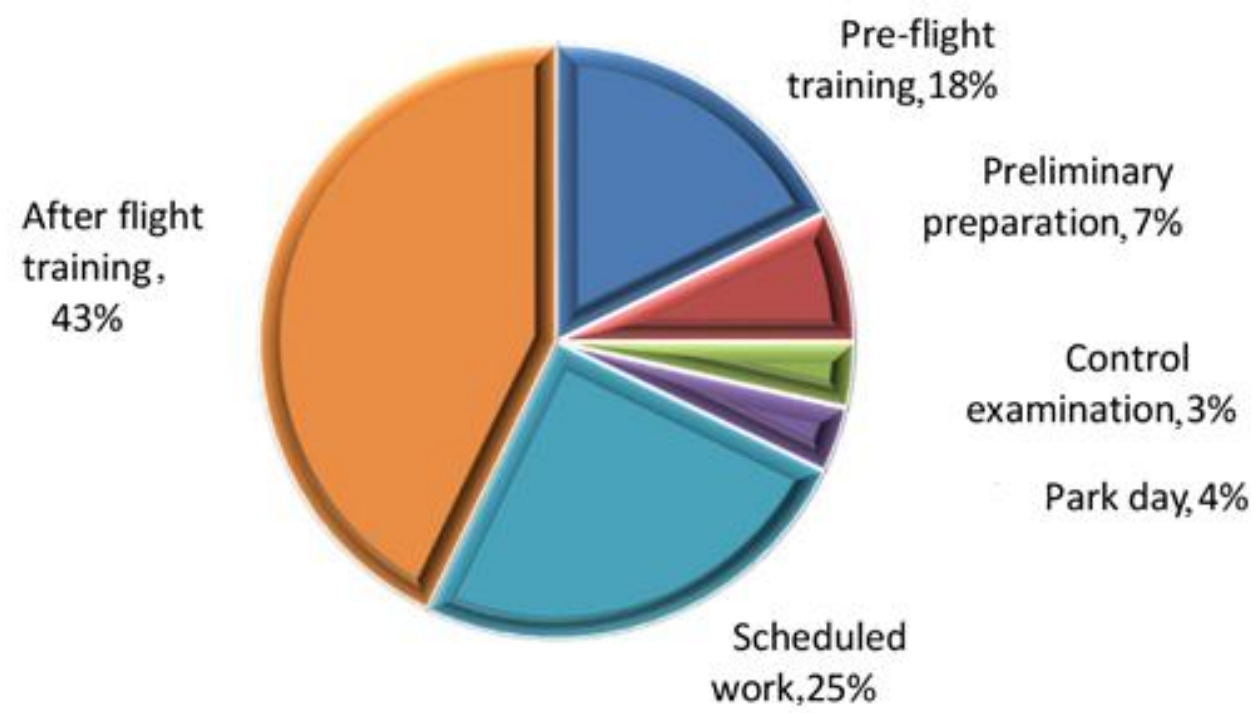

Figure 4. The structure of fault detection by type of work on the aircraft 

operation.

The second direction of the analysis of the flow of faults of the aircraft during their

The analysis shows that the flow is random and unexpected, and its occurrence can be considered as a flow of events in which faults are distributed according to Poisson's law. According to such properties of the fault flow, it is quite possible to determine the trend of changes in the level of reliability of the aircraft and its systems, using such a reliability indicator as the "fault flow parameter $z(t)$ " that characterizes the level of operational reliability. This indicator will be calculated as the ratio of the total number of faults to the total amount of aircraft flying hours with an accuracy of 0,001 with a confidence level of $\beta=0.95$. It can be used in the implementation of algorithms for controlling the output of the current values of the reliability of the aircraft beyond the pre-established control limits.

The results of the analysis of the reliability indicator $z(t)$ revealed that for the period 20162019 there is a gradual decrease in the reliability indicators of helicopters. As we can see from Figure 5 during this period, the "fault flow parameter $z(t)$ " for all types of helicopters increased by $63,2 \%$.

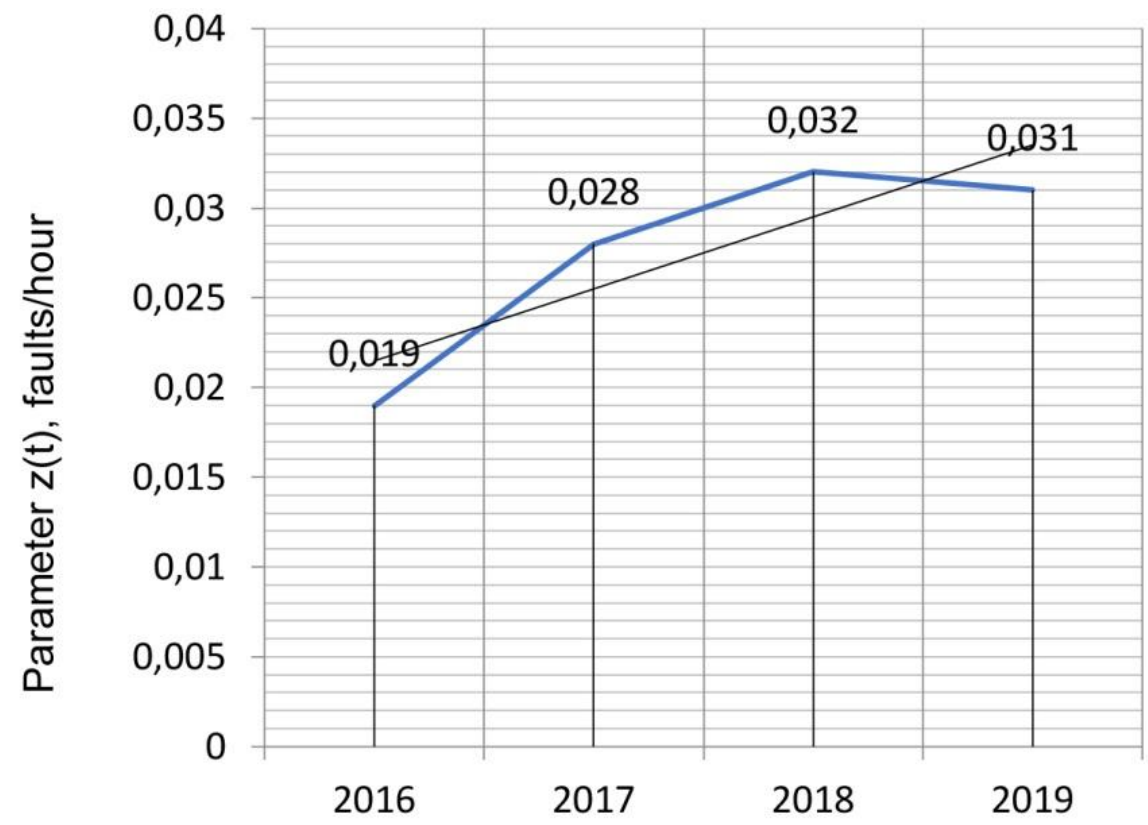

Figure 5. The general trend of changing the flow faults parameter of helicopters for all types

It is possible to try to ensure a high level of operational reliability of the aircraft by technical and organizational means, but it is unrealistic to make the aircraft completely, one hundred percent faultless, as there is a so-called "reliability barrier". However, it is quite possible to determine the trend of changes in the level of reliability of the aircraft and its systems, using the reliability index $z(t)$.

Based on this indicator, using the operating data of previous periods of the aircraft operation, necessity calculate the so-called "temporary upper control limit of reliability" $\left(\mathrm{MH}_{T B K}\right)$ [15].

The calculation of the $M H_{T B K}$ indicator is carried out according to the recommendation [15] according to the following formula:

$$
M H_{T B K}=m+k \sigma
$$

where: $m$ is the average value of the parameter $z(t)$ for 2016-2019;

$k$ is coefficient, which is usually taken in the range of $2-3$ and determines the width of the confidence interval;

$\sigma=\sqrt{\frac{1}{4} \sum_{1}^{4}(l-m)^{2}}$, where: $l$ is the value of the parameter $z(t)$ for the year.

The sequence and results of the calculation are shown in table 2. 
The results of the calculation of the indicator $M H_{T B K}$

\begin{tabular}{|c|c|c|c|c|c|}
\hline \multirow{3}{*}{ Year of operation } & \multicolumn{4}{|c|}{ Type of helicopter } & \multirow{2}{*}{ 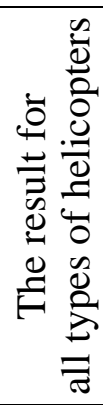 } \\
\hline & $\stackrel{\stackrel{N}{2}}{\Sigma}$ & 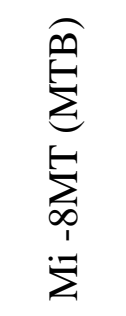 & $\begin{array}{l}D_{1} \\
\infty \\
\sum_{\infty}^{\infty} \\
\sum_{\infty}^{1} \\
\sum\end{array}$ & $\begin{array}{l}\stackrel{+}{N} \\
\stackrel{\Sigma}{\Sigma}\end{array}$ & \\
\hline & \multicolumn{5}{|c|}{ Fault flow parameter $z(t)$, faults/hour } \\
\hline 2016 & 0.016 & 0.015 & 0.041 & 0.016 & 0.019 \\
\hline 2017 & 0.055 & 0.029 & 0.024 & 0.026 & 0.028 \\
\hline 2018 & 0.055 & 0.027 & 0.036 & 0.037 & 0.032 \\
\hline 2019 & 0.090 & 0.026 & 0.034 & 0.038 & 0.031 \\
\hline \multicolumn{6}{|c|}{ The sequence of calculation of the indicator $M H_{T K B}$} \\
\hline$m$ & 0.054 & 0.024 & 0.034 & 0.029 & 0.028 \\
\hline$\sigma=\sqrt{\frac{1}{4} \sum_{1}^{4}(l-m)^{2}}$ & 0.026 & 0.005 & 0.007 & 0.009 & 0.006 \\
\hline$k$ & 2 & 2 & 2 & 2 & 2.5 \\
\hline Value $M H_{T B K}$ & 0.106 & 0.034 & 0.048 & 0.047 & 0.043 \\
\hline
\end{tabular}

The analysis of the obtained results makes it possible to determine, on the basis of operational data, the so-called orientating (forecast) indicators "temporary upper control limit of reliability" for 2020 for these types of helicopters.

According to the obtained results it is possible to predict:

- for Mi-2 helicopters, the acceptable upper value of the reliability control limit will be no more than 10.6 faults per 100 hours of flight;

- for Mi-8MT (MTV) helicopters - no more than 3.4 malfunctions per 100 hours of flight;

- for Mi-8MSB-V helicopters - no more than 4.8 malfunctions per 100 hours of flight;

- for Mi-24 helicopters - no more than 4.7 malfunctions per 100 hours of flight;

- for all types of helicopters, the average value of the forecast MHTBK, will be no more than 4.3 faults per 100 hours of flight.

Thus, in our opinion, we can consider the presented calculations as an attempt to establish certain normalized forecast indicators using data for previous periods of operation of the helicopter fleet of Ukraine.

The third area of research involves determining certain benchmarks of operational reliability, which must be achieved in subsequent periods of operation of the aircraft.

Determining the trend of changes in the level of operational reliability reveals the general technical condition of the helicopter fleet, but does not determine certain benchmarks that need to be achieved in subsequent periods of operation.

To determine the indicative thresholds of reliability, we use the concept of "acceptable level of safety performance" (ALoSP) [16]. ALoSP is a comprehensive concept, while safety indicators with appropriate alert levels and target levels are actual indicators. ALoSP is a combination of several performance objectives, measured by safety performance, and action plans needed to achieve the set objectives.

The results of the calculation of the set of indicators "fault flow parameter $z(t)$ " for helicopters for the period 2016-2019 are summarized in table 3. 
Збірник наукових прачь Державного науково-дослідного інституту випробувань і сертифікачії озброєння та військової техніки. 2021. Вип. № 3(9)

ISSN 2706-7386

The analysis of the results shown in Table makes it possible to determine on the basis of operational data the so-called orientating reliability indicators of the concept of ALoSP for 2020 for these types of helicopters.

Table 3.

The results of the calculation of AloSP

\begin{tabular}{|c|c|c|c|c|c|}
\hline \multirow{3}{*}{ Year of operation } & \multicolumn{4}{|c|}{ Type of helicopter } & \multirow{2}{*}{ 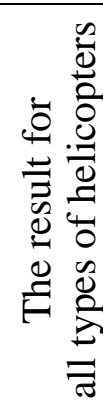 } \\
\hline & $\stackrel{i}{i}$ & $\begin{array}{l}\sum_{\infty}^{\infty} \widehat{N} \\
\sum_{i} \sum\end{array}$ & $\begin{array}{l}\sum_{\infty}^{\infty}> \\
\sum_{\infty}^{\infty}>\end{array}$ & $\begin{array}{l}\stackrel{+}{1} \\
\stackrel{2}{\Sigma}\end{array}$ & \\
\hline & \multicolumn{5}{|c|}{ Fault flow parameter, $z(t)$, faults/hour } \\
\hline 2016 & 0.016 & 0.015 & 0.041 & 0.016 & 0.019 \\
\hline 2017 & 0.055 & 0.029 & 0.024 & 0.026 & 0.028 \\
\hline 2018 & 0.055 & 0.027 & 0.036 & 0.037 & 0.032 \\
\hline 2019 & 0.090 & 0.026 & 0.034 & 0.038 & 0.031 \\
\hline \multicolumn{6}{|c|}{ The sequence of calculation of the indicators ALoSP } \\
\hline$m$ & 0.054 & 0.024 & 0.034 & 0.029 & 0.028 \\
\hline$\sigma=\sqrt{\frac{1}{3} \sum_{1}^{4}(l-m)^{2}}$ & 0.017 & 0.004 & 0.004 & 0.006 & 0.003 \\
\hline$k$ & 2 & 2 & 2 & 2 & 2 \\
\hline \multicolumn{6}{|c|}{ The value of indicators ALoSP } \\
\hline Acceptable & 0.051 & 0.023 & 0.032 & 0.028 & 0.027 \\
\hline Target & 0.068 & 0.027 & 0.036 & 0.034 & 0.030 \\
\hline Alert & 0.085 & 0.031 & 0.040 & 0.040 & 0.034 \\
\hline
\end{tabular}

According to the results obtained, it is possible to predict in terms of 100 hours of flight for 2020:

1) acceptable level of reliability (Acceptable):

- for Mi-2 helicopters 0.051, ( no more than 5.1 faults);

- for Mi-8MT (MTV) helicopters - 0.023, (no more than 2.3 malfunctions);

- for Mi-8MSB-V helicopters - 0.032, (no more than 3.2 malfunctions);

- for Mi-24 helicopters - 0.028, (no more than 2.8 faults);

- for all types of helicopters, the average value of the Acceptable forecast will be no more than 2.7 faults;

2) target level of reliability (Target):

- for Mi-2 helicopters 0.068 , (no more than 6.8 faults);

- for Mi-8MT (MTV) helicopters - 0.027, (no more than 2.7 faults);

- for Mi-8MSB-V helicopters - 0.036, (no more than 3.6 malfunctions);

- for Mi-24 helicopters - 0.0384, (no more than 3.4);

- for all types of helicopters, the average value of the Target forecast will be no more than 3.0 faults;

3) critical level of reliability (Alert):

- for Mi-2 helicopters 0.085 , (no more than 8.5 faults);

- for Mi-8MT (MTV) helicopters - 0.031, (no more than 3.1 malfunctions);

- for Mi-8MSB-V helicopters - 0.040, (no more than 4.0 malfunctions);

- for Mi-24 helicopters - 0.040, (no more than 4.0 malfunctions);

3.4 faults.

- for all types of helicopters, the average value of the Alert forecast will be no more than 
The extrapolation results of the obtained values of orientating threshold indicators of reliability of the ALoSP concept for 2020-2021 for all types of helicopters are shown in Figure 6.

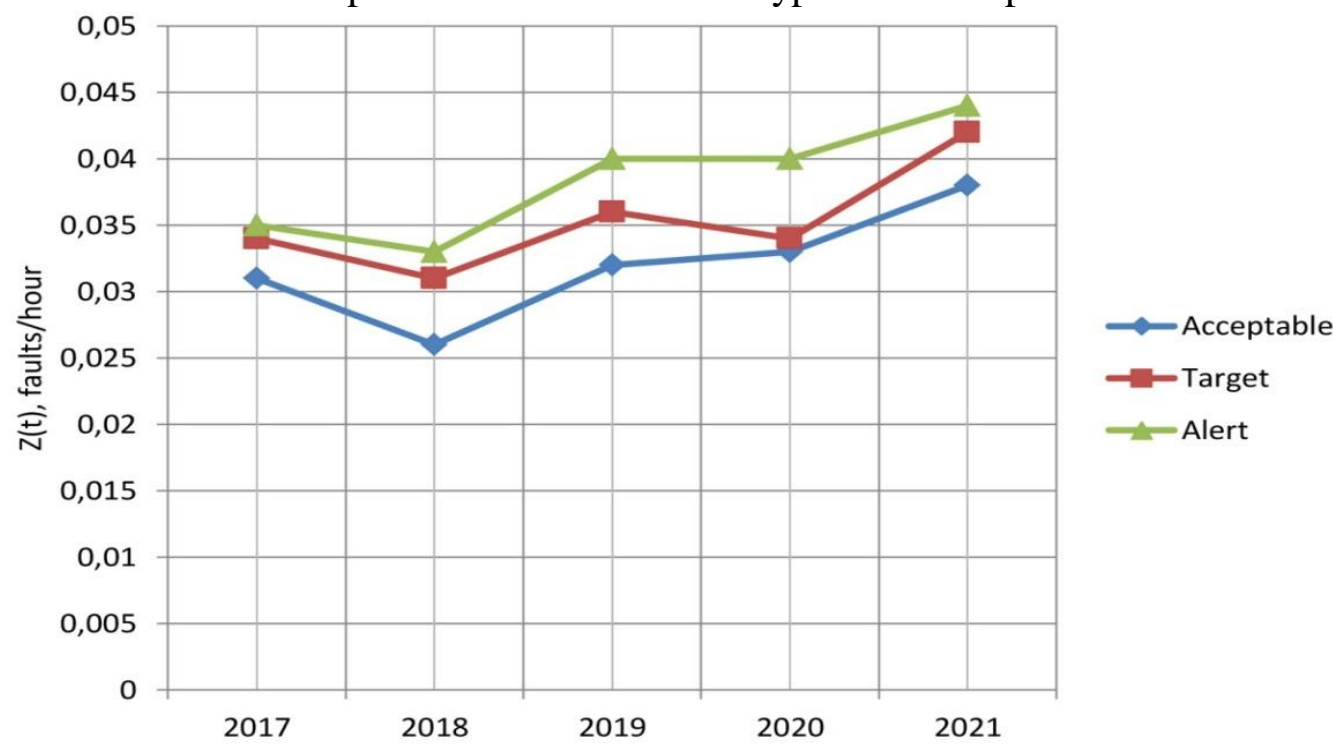

Figure 6. Indicative reliability thresholds of the ALoSP concept of the helicopter fleet of the state aviation of Ukraine

Thus, we can consider the presented calculations as an attempt to determine some normalized forecast range of values of reliability indicators for the future period of operation of the government fleet helicopters.

In this regard, an interesting area of forecasting reliability indicators is also the possibility of applying the doctrine of conditional optimization of entropy of hybrid functions, developed to determine certain reliability characteristics, including taking into account the intensity and parameters of event flows regarding system transitions to fault state and failure state [17-18]. This may be the direction of further research on the problem discussed in this article.

\section{Conclusions}

Based on the previously developed methodology [19], an analysis of the problem of determining the trend of changes in the reliability of helicopters was performed. It showed that for a reliable assessment it is necessary to constantly monitor flight safety and identify and process statistics of the causes that lead to malfunctions of aircraft, their systems and subsystems.

The implementation of a methodological approach to determine the "temporary upper reliability limit" for different types of helicopters makes it possible to develop forecasts of the level of reliability of the aircraft and set targets that need to be maintained or improved in order to improve a particular aviation system.

The introduction of the ALoSP concept allows aviation entities to work better in the direction of improving the operational reliability of the aircraft, which will ultimately contribute to improving the level of flight safety.

Developed proposals for determining orientating indicators of reliability through the collection and processing of information on the technical condition during the military operation of the aircraft will effectively manage reliability systems to maintain high combat readiness of state aviation at a given level, predict the need for maintenance and repair of aircraft.

\section{REFERENCES}

1. Vorobiev V G 2010 Reliability and technical diagnostics of aviation equipment (Moscow: Moscow State Technical University of Civil Aviation Press) 440 p.

2. Glowacki P, Loroch L and Balicki V 2018 Operations reliability study of small aircraft powered by piston engines. Aircraft Engineering and Aerospace Technology. DOI:10.1108/AEAT01-2018-0005.

3. Guziy A G, Lushkin A M and Rosina O A 2009 Development and implementation problems of the safety management system in airlines. The analysis of their causes and solutions. Problems of flight safety 1. - P. 11-22. 
4. Zio E, Fan M, Zeng Z and Kang R 2019 Application of reliability technologies in civil aviation: Lessons learnt and perspectives. Chinese Journal of Aeronautics 32 Issue 1.- P. 143-158.

5. Makhitko V P 2016 Method for assessing flight safety by quantitative indicators of reliability of functional aircraft systems Proceedings of the Samara Scientific Center of the Russian Academy of Sciences 18 №1 (2). - P. 369-372.

6. Convention on International Civil Aviation. Doc 7300/8, Eighth Edition. - Montreal: ICAO, 2000.

7. Safety Management Manual. Doc.9859 AN/474. 3rd Edition. - Montreal: ICAO, 2013.

8. Annex 19 - Safety Management, Second Edition - Montreal, ICAO, 2016.

9. Sharov V D 2007 Development of a safety indicator based on ICAO recommendations. Flight safety issues. - Moscow: VINITI. - P. 10-18.

10. Голуб В.М. Аналіз методичних підходів до оцінювання надійності авіаційної техніки державної авіації за експлуатаційними даними / В.М.Голуб, А.Г.Павленко, О.М. Чередніков, В.М. Чуприна // Збірник наукових праць Державного науково-дослідного інституту випробувань і сертифікації озброєння та військової техніки. - Чернігів: ДНДІ ВС OBТ, 2019. - Вип. № 2. - С. 53-61.

11. Голуб В.М. До питання аналізу експлуатаційної надійності та безпеки польотів повітряних суден. / В.М. Голуб, М.М. Жданюк, В.Т. Бояров, В.М. Чуприна, Е.Ф. Сідін // Тринадцята міжнародна науково практична конференція "Математичне та імітаційне моделювання систем МОДС 2019”. До 100 - річчя Національної академії науки України. Київ - Чернігів - Жуків, 25-29 червня 2018 р. - Чернігів: ЧНТУ, 2018. - С. 379-381.

12. Експлуатаційна надійність авіаційної техніки і безпека польотів за 2017 рік. Випуск. / В.М. Голуб, О.М. Чередніков, В.Т. Бояров, М.М. Жданюк. - Чернігів: ДНДІ ВС ОВТ, 2018. $-90 \mathrm{c.}$.

10. Експлуатаційна надійність авіаційної техніки і безпека польотів за 2018 рік. Випуск. / О.Л. Бурсала, В.Т. Бояров, В.М. Голуб, М.М. Жданюк, Е.Ф. Сідін. - Чернігів: ДНДІ ВС ОВТ, 2019. - $100 \mathrm{c}$.

11. Експлуатаційна надійність авіаційної техніки і безпека польотів за 2019 рік. Випуск. / В.М. Голуб, О.М. Чередніков, В.Т. Бояров, М.М. Жданюк. - Чернігів: ДНДІ ВС ОВТ, 2020. $-107 \mathrm{c}$.

13. Chernyavsky V M 2012 Application of parametric methods for assessing the level of reliability of aircraft with low intensity of operation Proceedings of Kharkiv University of the Air Force named after I. Kozhedub (Kharkiv: HUPS Press). - № 3. - P. 59-63.

14. Goncharenko E V and Martyniuk O R 2019 On the application of the concept of the accepted level of flight safety in the aviation activities of state aviation Proceedings of the 18th scientific and technical conference "Creation and modernization of armaments and military equipment in modern conditions" (Chernihiv: DNDI VS OVT). - P. 89.

15. Goncharenko A 2018 A multi-optional hybrid functions entropy as a tool for transportation means repair optimal periodicity determination Aviation. - № 22(2). - P. 60-66. - DOI:10.3846/aviation.2018.5930.

16. Goncharenko A V. 2018 Aeronautical and aerospace material and structural damages to failures: theoretical concepts International Journal of Aerospace Engineering. - Volume 2018(2018). - P. 1-7.

17. Голуб В.М. Методологічний підхід до визначення тренду змін показників надійності авіаційної техніки на прикладі вертольотів державної авіації / В.М. Голуб, О.Л. Бурсала, B.М. Чуприна // Збірник наукових праць Державного науково-дослідного інституту випробувань і сертифікації озброєння та військової техніки. - Чернігів: ДНДІ ВС ОВТ, 2020. - Вип. № 4(6). С. 42-51. - DOI: 10.37701/dndivsovt.6.2020.05.

\section{Бурсала Олександр Леонідович}

кандидат технічних наук, старший науковий співробітник, начальник відділу Державного науково-дослідного інституту випробувань і сертифікації озброєння та військової техніки, Чернігів, Україна https://orcid.org/0000-0002-8523-8987

$+38099-478-89-25$

\section{Oleksandr Bursala}

Candidate of Technical Sciences, Senior Researcher, Chief of Section of State Scientific Research Institute of Armament and Military Equipment Testing and Certification, Chernihiv, Ukraine https://orcid.org/0000-0002-8523-8987 $+38099-478-89-25$ 


\section{Голуб Володимир Маркович}

кандидат технічних наук, доцент, провідний науковий співробітник Державного науководослідного інституту випробувань і сертифікації озброєння та військової техніки, Чернігів, Україна

https://orcid.org/0000-0002-7796-3054 +38097684-64-51

\section{Чередніков Олег Миколайович}

кандидат технічних наук, доцент, старший науковий співробітник Державного науководослідного інституту випробувань і сертифікації озброєння та військової техніки, Чернігів, Україна https://orcid.org/0000-0003-1285-590X +38050-297-83-98

\section{Чуприна Володимир Михайлович}

доктор технічних наук, доцент, провідний науковий співробітник Державного науководослідного інституту випробувань i сертифікації озброєння та військової техніки, Чернігів, Україна https://orcid.org/0000-0003-4886-090X +38068-131-66-06

\section{Коваленко Ігор Володимирович}

Начальник 1285 військового представництва Міністерства оборони України, Київ, Україна

https://orcid.org/0000-0003-4634-0943

$+38066277266$

\section{Volodymyr Golub}

Candidate of Technical Sciences, Associate Professor, Lead Researcher of State Scientific Research Institute of Armament and Military Equipment Testing and Certification, Chernihiv, Ukraine

https://orcid.org/0000-0002-7796-3054 +38097-684-64-51

\section{Oleg Cherednikov}

Candidate of Technical Sciences, Associate Professor, Senior Researcher of State Scientific Research Institute of Armament and Military Equipment Testing and Certification, Chernihiv, Ukraine https://orcid.org/0000-0003-1285-590X +38050-297-83-98

\section{Volodymyr Chupryna}

Doctor of Technical Sciences, Associate Professor, Lead Researcher of State Scientific Research Institute of Armament and Military Equipment Testing and Certification, Chernihiv, Ukraine https://orcid.org/0000-0003-4886-090X +38068-131-66-06

\section{Ihor Kovalenko}

Chief of the 1285 Military Representatives of the Ministry of Defense of Ukraine, Kyiv, Ukraine https://orcid.org/0000-0003-4634-0943 $+38066277266$

\section{ВИЗНАЧЕННЯ ПОКАЗНИКІВ ЕКСПЛУАТАЦІЙНОЇ НАДІЙНОСТІ АВІАЦІЙНОЇ ТЕХНІКИ 3 ВРАХУВАННЯМ РЕКОМЕНДАЦІЙ ІСАО \\ Бурсала О.Л., Голуб В.М., Чередніков О.М., Чуприна В.М., Коваленко І.В.}

На основі розробленої передової методології, яка враховує вплив умов експлуатації та режимів на стан авіаційної техніки (літаків, вертольотів), їх конструкиію та правила експлуатації, представлені результати визначення рівня експлуатаційної надійності та орієнтовні показники надійності вертольотів та їх функціональних систем. Наведено алгоритм обробки статистичної інформації, щчо надходить з авіаційних частин державної авіачії відповідно до методичних рекомендачій у вигляді звітів та карток обліку несправностей, в яких узагальнюються оперативні дані.

Предметом роботи є визначення показників експлуатаційної надійності та безпеки польотів 3 урахуванням рекомендацій Міжнародної організації цчивільної авіації ІСАО на основі статистичних даних про несправності, щуо виникають під час експлуатачії літальних апаратів.

Визначено перелік та основні причини зміни показників надійності на 2016-2020 роки. На прикладі вертольотів державної авіаџії України представлені результати обробки, аналізу та розрахунків експлуатаційної статистики окремих типів вертольотів та розрахунки середніх показників їх експлуатаційної надійності.

На основі розробленої методології шляхом екстраполювання отриманих даних здійснена прогнозна оцінка несправностей літальних апаратів. Таким чином визначені нормовані інтервали прогнозування значень показників надійності вертолітного парку Украӥни на майбутній період 2021-2022 років.

Ключові слова: авіаційна техніка, вертоліт, несправність, експлуатаційна надійність, безпека польотів, методологія, рекомендачії ICAO. 